\title{
IN SEARCH OF CONSTITUTIONALITY: FREEDOM OF EXPRESSION AND INDONESIA'S ANTI-PORNOGRAPHY LAW
}

\author{
R. Herlambang Perdana Wiratraman \\ Fakultas Hukum Universitas Airlangga, herlambangperdana@yahoo.com
}

\begin{abstract}
In 2008 vehement debates about the freedom of expression divided Indonesia, after the government resubmitted a bill for Anti-Pornography to Parliament. The various sides employed all kinds of arguments and perspectives, the main ones being religious versus human rights and pluralism. The main problem of the new law is its vague and very broad definition of pornography, which could threaten women's rights, cultural expression and press freedom. In the context of democratization in Indonesia post Soeharto, freedom of expression has been progressively promoted, particularly by the adoption of a Constitutional guarantee for freedom of expression. Nevertheless, the constitutionality of freedom of expression still needs to be comprehensively re-explored in order to advance human rights and democracy development.
\end{abstract}

Key words: Anti-Pornography, Freedom of Expression, Human Rights

\section{Introduction}

Since the beginning, the draft of antipornography law has been controversial. Unsurprisingly, the draft soon sparked heated debate in various region of the country, particularly among the communities or groups that had different cultural values and religious belief than the one adhered by the legislators who supported the draft. This draft, finally, was enacted last year by parliament and government through pornography law (Law Number 44 of 2008).

There are divided at least into two major groups who opposing each other. One is the supporter of legal formalization over anti-pornography, who mostly backed up by Muslim conservative groups. The other group is a number of group who opposing the enactment of pornography law. Although opposing the enactment of pornography law, they always show disagreement to pornography.

The enactment of Pornography Law is based on article 28B section (2), 28J section (2), and 29 Indonesia Constitution. In other simpler words, from these articles, these are explicitly designed to address the protection of children from pornography, pornography should be limited by law, and law is based on religion perspective. 
This paper will limit by discussing the constitutionality idea of anti-pornography law, in the framework of freedom of expression as one of constitutional rights. It is benefited by the process of judicial review of this law in Constitutional Court which has been starting since February 2009 until now, because, beside the main document sources, also the debate came into more formal and legal way before the constitutional court judges. By using the review proposal documents, it can be clearly seen which articles are disputed by applicant in Constitutional Court.

The main question is, whether the anti-pornography law has reflected constitutionality, especially in limiting freedom of expression and respecting antidiscrimination principle. Constitutionality here is defined as the quality or state of being constitutional, especially accordance with the provision of a constitution.

As mentioned above, it takes several articles which are disputed by applicant into Constitutional Court. There are three group applicants, first, applied by National Committee of Indonesian Youth or Komite Nasional Pemuda Indonesia, North Sulawesi, et all. (KNPI Sulut et. all); second, applied by Koalisi Perempuan Indonesia untuk Keadilan dan Demokrasi (KPIKD et all); and third, applied by LBH Apik Foundation et all.

From those applicants, there are several articles that proposed to be reviewed. These articles can be grouped below.

\begin{tabular}{|l|l|l|}
\hline \multicolumn{1}{|c|}{ Group } & Case Number & $\begin{array}{l}\text { R e v i e w e d } \\
\text { Articles }\end{array}$ \\
\hline $\begin{array}{l}\text { KNPI Sulut et } \\
\text { all }\end{array}$ & $\begin{array}{l}10 / \text { PUU- } \\
\text { VII/2009 }\end{array}$ & $\begin{array}{l}\text { Article } 1.1 ; 4 \\
(1) \text { and } 10\end{array}$ \\
\hline KPIKD et all & $17 /$ PUU- & $\begin{array}{l}\text { Article } 1.1 ; 4 \\
(1) ; 20 ; 21 \text { and } \\
\text { VII/2009 }\end{array}$ \\
\hline $\begin{array}{l}\text { LBH Apik } \\
\text { Foundation et } \\
\text { all }\end{array}$ & VII/2009 & $\begin{array}{l}\text { Article } 1.1 ; 4 \\
(1) ; 10 ; 20 ; \text { and } \\
23\end{array}$ \\
\hline
\end{tabular}

Regarding to those reviewed articles, what are basically the main problem of pornography law? This study has detected at least four major problems of pornography law.

First, this law highly possible invites multi-interpretation because its text has unclear provision. Article 1.1 of Pornography Law defines pornography as "sexual material that includes photographs, cartoons, films, poems, vocalization, conversations and body gestures in the media, or in public shows, exhibits or performances." This definition sets a decidedly moral tone without a clear standard or methods of evaluating what "sexual desire" actually is or what "incitements" includes. By having unclear standard to measure these articles, unfortunately, it would be more orchestrated by dominant group in society.

On the other side, there are some differences measuring values. In Bali, some of daily activities could be categorized as pornography, such as tradition or religious belief.

Second, in the patriarchal society, this law would be arbitrarily interpreted and used to pressure or even violate against "suspected individual or group", especially women as victim. The implementation 
of Shari'a District Law in Tangerang has given experience that prohibits women to go out during night hours, without considering women who are working at night, poor women who have longer working hours either in formal or informal sectors. The most dangerous consequences from this point of view is it would be more uncontrolled violation and discrimination against women.

Third, this pornography law assumes the need of women and children protection against pornography as a purpose (vide: Article 3.d of Pornography Law). Nevertheless, this assumption failed to portray actual women condition, position and psychological in society, particularly women as violence victim. The content of Pornography Law does not locate women as objects who are victimized in pornography industry, but it expresses women as legal subject who involve to sustain pornography industry and its distribution.

Fourth, the absence of constitutional rights perspective. The law did not mention the importance article 28C section (2), 28D section (1), 28E section (2), 28I section (2) and (3) Indonesia Constitution. This absence is very risky, because the pornography law did not pay sufficient attention to the law of the Constitution, or other constitutional rights, which are actually becoming important since Indonesia's Constitution had more complete human rights provision.

In this regard, the issue of freedom of expression is an important point related to the enactment of anti-pornography law, because this law affects and tends to limit certain expression which is assumed contravene against morality or religious perspectives. In the context of democratization in Indonesia post-Suharto, freedom of expression has been progressively promoted, particularly by the adoption of a Constitutional guarantee for human rights. Nevertheless, the constitutionality of freedom of expression still needs to be comprehensively reexplored in order to advance human rights and democracy development.

The next part assesses the legal and the practical limits to freedom of expression, which is based on human rights standard, as key analysis to criticize the (in) constitutionality of pornography law.

\section{Freedom of Expression and the Guarantee of UUD 1945}

Conceptually, the idea of freedom of expression has been introduced since the first constitution in 1945, especially under article 28. The development of human rights thoughts in Indonesian constitutional thought history has been influenced by human rights struggle in 18th century, after the explosion of people revolution in United States and France. This revolution has inspired to highlight the concept of rights, particularly in acquiring civil liberties or human rights in political processes. This is then uplifted on parliament meetings during constitutional changes and conceptualized as civil and political rights (Wiratraman 2009). 
The formulation of freedom of expression became extensive and more progressive since the second constitution amendment in 2000. Article 28E of the new constitution has added the religious and faith expression, freedom of thought, freedom of opinion, freedom to assemble and unite. Shortly, all kinds of expression are widely adopted by constitution as fundamental rights or freedom.

Although it has an extensive provision over freedom of expression, rightly, it does not mean those rights without limitation. The constitution has adopted a model of limitation as well in order to protect and fulfil other rights, as mentioned at article 28J section (2) (vide: footnote 4).

Interestingly, the Pornography Law has adopted this article to justify certain limitation against pornography. Under this article, there are four elements to limit rights or freedom, which are morality, religious values, security, and public order. In the human rights framework, this is concerned by Syracuse Principles (1985). These principles have limitation clauses, which divided into two: (A) General Interpretative Principles Relating to the Justification of Limitations; and (B) Interpretative Principles Relating to Specific Limitation Clauses.

The General Interpretative Principles Relating to the Justification of Limitations has 14 principles. Some of them are needed to mention here, which are "All limitation clauses shall be interpreted strictly and in favor of the rights at issue (Principle 3); All limitations shall be interpreted in the light and context of the particular right concerned. (Principle 4); No limitation shall be applied in an arbitrary manner (Principle 7); No limitation on a right recognized by the Covenant shall discriminate contrary to Article 2, paragraph 1 (Principle 9).

The Interpretative Principles Relating to Specific Limitation Clauses has 23 principles (Principle 15-38), which divided into 9 specific limitation. Regarding article $28 \mathrm{~J}$ section (2), this paper only relates into three specific principles, which are: Legal rules limiting the exercise of human rights shall be clear and accessible to everyone (Principle 17, under the term "prescribed by law"); and the term "public moral" provide two principles: Since public morality varies over time and from one culture to another, a state which invokes public morality as a ground for restricting human rights, while enjoying a certain margin of discretion, shall demonstrate that the limitation in question is essential to the maintenance of respect for fundamental values of the community (Principle 27), and The margin of discretion left to states does not apply to the rule of non-discrimination as defined in the Covenant (Principle 28).

By understanding Syracuse principle and those are specific related to article, actually Indonesia Constitution also provided non-discrimination provision. Under article 28I Section (2) of Constitution, says "Each person has the right to be free from acts of discrimination based on what grounds ever and shall be entitled to protection against such discriminative treatment." Interestingly, the Constitution also provides the guarantee 
of pluralism, as mentioned at article 28I Section (3): “The cultural identities and rights of traditional communities are to be respected in conjunction with progressing times and civilization." This article should be considered as a constitutional guarantee of cultural expression, which is inseparable with the previous article about nondiscrimination provision.

The requirement for discretion, once again, as stressed in the context of "public moral" (Principle 27-28) should be based on both (1) respect fundamental values of the community and (2) non-discrimination. And this is also clearly enough adopted as constitutional rights in Indonesia's Constitution.

\section{Morality of Law and Plural Society}

"Masalah pornografi adalah masalah moral dan bukan masalah kekerasan terhadap perempuan. Presiden lebih baik memberantas pornografi dan pornoaksi.

Sebab dua hal itulah, perusak moral bangsa yang sesungguhnya"

(Chairman of Fatwa Commission, Indonesia Ulama Assembly (MUI),

KH. Ma'ruf Amin, http://www.mui. or.id/mui_in/news).

Can there be law without morality?

Harding (1956: p. 28-53) has already answered this issue, by proposing a sociological concept of law. He says that in pursuing the relationship of law and morality of law, we must formulate a concept of law lying somewhere between the two extremes suggested. First, law as a human institution; and second, law as a social institution.

If it considers law as a human institution, it is equally important that we insist that it is human. To reduce law to a verbal rule, is to remove the inquiry so far from actuality as to make any study worthless. Also, it is important that we avoid excesses in this direction. One is the point of view popularized by the historical jurist of the nineteenth century. It was something which had to develop in the experience and development of a people, something which reflected the essence or spirit of that people. The other excess is the tendency of some of our current crop of legal realist to define law solely in terms of judicial decision - to define law as the result to be reached in a particular case "and nothing more".

As a social institution, it is an institution created by men living in a political state is employed by men to order the society and to settle controversies between individuals, or between individual and state.

What Harding suggested (1956: 4243 ), we should consider law not in terms of source, nor in terms of form, but in terms of the functions which it performs in the society. If we consider law functionally as a social institution, there are three principal aspects. First, how and by whom and on what basis are the standards of general application formulated? Secondly, what is the nature of the sanction, what is it that induces the individual subject or citizen to conform to the standard set? Finally, on what basis and in what manner are the standards 
to be applied what is the actual basis of law administration?

In the context of Pornography law, as we have seen this was a legal product made by parliament and government which had been reproduced to control the effect of sex commercialization and protection over women and children. This idea has no doubt to be accepted by many parties, especially those who had political authority at that time, but on the other side, it has failed to convince public to believe that this law would protect women and children.

The major reason is related to law paradigm behind it. If the dominant perspective of legal enforcer still have patriarchal paradigm, moreover, many fundamentalist group still use violence to pressure against -- in defense of 'morality' or 'religious morality' and what they assumed as -- pornography, unsurprisingly that this law would be functioning as an effective ammunition to enlarge more violence, and again, human rights would be easily marginalized.

From empirical point of view, the state had failed to prevent this kind of violence. The state was quite easily silent and too late in responding conflict among communities. Morality in this regard, should be brought into society dialogue, and the State should actively promote and facilitate this dialogue, as part of human rights respecting and protection. Quoted from Immanuel Kant, the function of the State is to guarantee individual freedom in law, so then each individual still has freedom to gain happiness by using any manner which he/she considers as good, as long as it does not marginalize freedom and rights of other subject surrounding them (Tjahjadi 1991: 63).

This paper agree to Rahardjo (2003: 5559), who says that since the modern law has been dominant in society relation, morality has been significantly eroded. He suggested that the morality should be highlighted, and law need morality as an important spirit to dispense justice. Nevertheless, in the diverse society, talking about morality is not an easy thing. During expert witness process in Constitutional Court (Wednesday, 6 May 2009), Soetandyo Wignjosoebroto, a sociology of law professor, said that "values and moral difference in plural society is a 'given' thing, which cannot be avoided. Pushing certain values, norm or concept based on law, with centralistic control mechanism would only result controversies."

Inline with Wignyosoebroto, in the next Constitutional Court session (27 August 2009), Rocky Gerung, a philosopher from University of Indonesia, said that "it is really difficult to say disagreement against logic or law propositions which are based religion argumentation, because religion argumentationis final! If we want to scrutinize public thinking, we have to assume that the argumentation is not final yet." He added that "the relation among citizen should be assessed from constitutional provision, not from the holy verses."

Pornography law is extremely sensitive law in the context of very plural society in 
Indonesia, because every community group has own fundamental values to see their way of life. So that is why the issue of morality should be based on pluralism context and human rights protection. Of course, in order to understand this pluralism context, we need seriously to unravel sociological background of Pornography law. It is because it would prevent a conflicting situation among social communities in defending their fundamental values without having opportunity to dialogue common ideas and values. By understanding this background, Pornography law can be properly discussed in the sense to respect, protect and advance human rights as main purpose in making law.

\section{'Democratizing' Pornography Law}

Should we democratize Pornography law? This question come out when I am trying to imagine the compromise prescription over Pornography law.

Inevitable, the idea of 'religion' or 'morality' has significantly contributed to the making of Pornography law. Indeed, according to Constitutional Law, Indonesia Constitution allows "religious values" as a value to limit or derogate certain rights. As we have seen, Pornography law laid down to article 28J section (2) Indonesia Constitution, which consider 'religion' or 'morality' as standard to limit rights.

There are two approaches to interpret this article in the context of democratizing law. The first, by applying principles of good governance in law making process; and second, by exploring a substantive consensual ideas, norms, and other fundamental values in the society.

We have Law Number 10 of 2004 concerning Law Making, which provided general principle and procedure to make law. According article 5 (f) of Law Number 10 of 2004, there are principle in law making,

a. Clear purpose/aim;

b. Authoritative organ or institution who make the law;

c. The matching between form and content;

d. Implementable;

e. The use and outcome;

f. Clear formulation; and

g. Openness

As explained above, the term or definition under article 1.1 and 4 section (1) of Pornography Law is not clear enough and opens multi interpretations which are quite dangerous in the sense of law implementation. From this point of view, it makes at least two problems: first, the unclear definition and formulation about decency concept in the context patriarchal society would depend on cultural aspects of society, which we have known that the culture among society is quite diverse. Second, the definition of pornography that is based on decency norm of patriarchal society would cause unjust and unequal for women, which also means that it would make undemocratic situation and adverse for human rights protection. 
In this regard, Pornography Law had basically failed to fulfill the requirement of principle of clear purpose/aim, principle of the matching between form and content and principle of clear formulation. Unsurprisingly, it would be difficult and always controversial implemented in the field thereafter.

Beside that, more importantly for second approach is related to the substance or content. It always involves question to what extent 'religion' or 'morality' contributes to or shapes the development of human rights, and how the state institutions explore and respond to these issues. It is simply because we have not only one religion, and also one morality standard, because those things are both influenced by diverse cultural experience and values which have been socialized to each individual or social community. These are dynamic and cannot be simply standardized. Therefore, the State should be actively looking for common fundamental values in the society in order to strengthen and sustain social and cultural relation.

This approach is the challenge for the State and society to transform democratization on the basis of capacity to revitalize fundamental values.

The 'democratic capacity' of the State in this regard can be examined at several fundamental issues. First, the State should be able to find the law with responsive character. This idea has been introduced by Nonet and Selznick (2001), through their famous law book, "Law and Society in Transition:
Toward Responsive Law". Responsive law is characterized in a democratic state. This typology of law is original and especially useful because it incorporates both political and jurisprudential aspects of law and speaks directly to contemporary struggles over the proper place of law in democratic governance.

Second, law should reflect the need of society and its consensus among them. Although the parliament member can make a claim that they are representing people or citizen, but they still need to 'communicate' and 'dialogue' with the people and facilitate them to e able in highlighting their ideas. So then, the representative can be always aware with political, social and cultural aspirations and expression, and accommodate it into policy or legislation. If there is a serious controversial issue, such as the enactment of Pornography Law, it means that the State must (re)confirm their policy or legislation and dialogue it with people. Otherwise, it would more affect the affectivity and ability of law.

The third, this is related to whether the law meets with human rights standard, especially with constitutional rights as fundamental law in the country. The amendment of constitution recognized either civil and political rights or economic, social and cultural rights, and these have been strengthened by ratification of both International Covenant through Law Number 11 and 12 of 2005. The principle of non-discrimination, equality, and human dignity are important to be considered by Pornography Law. Included, cultural 
rights of the peoples are as a part of socio, economic, and cultural rights.

\section{Conclution :}

In this regard, this paper concludes that in order to promote democracy development, the State should be not too quick satisfy in making law without considering constitutionality of law, which not only based on democratic procedural mechanism, but it is more challenge to highlight a 'democratic capacity' in order to respect, protect and fulfill human rights.

\section{Reference Book :}

Harding, Arthur L. "Can There Be Law Without Morality?", in Robert E Fitch et all, Religion, Morality and Law. Dallas: Southern Methodist University Press, 1956.

Nonet, Philip and Philip Selznick, Law and Society in Transition: Toward Responsive Law. New York: Harper and Row, 1978.

Satjipto Rahardjo "Negara Hukum tanpa Moral dan tanpa Disiplin", in Sisi-Sisi Lain dari Hukum di Indonesia. Jakarta: Penerbit Buku Kompas, 2003.

Vlies, Inge Cornelia van der, Het wetsbegrip en beginselen van behoorlijke regelgeving. 's-Gravenhage: Vuga, 1984.

Wiratraman, R. Herlambang Perdana, Good Governance and Legal Reform in Indonesia. Bangkok: OHRSD Mahidol University, 2007.

\section{JOURNAL :}

Wiratraman, R. Herlambang Perdana, "Kebebasan Bereskpresi: Penelusuran Pemikiran dalam Konstitusi Indonesia", Jurnal Konstitusi, Volume 6 Nomor 1, April 2009, Jakarta: Mahkamah Konstitusi, 2009.

Tjahjadi, S.P. Lili, Hukum dan Moral: Ajaran Immanuel Kant tentang Etika dan Imperatif Kategoris. Jakarta: Kanisius, 1991.

Constitutional Court, Constitutional Court Proceeding, Case Number 10/PUUVII/2009, http://www.mahkamahkonstitusi. go.id/

Constitutional Court, Constitutional Court Proceeding, Case Number 17/PUUVII/2009, http://www.mahkamahkonstitusi. go.id/

Constitutional Court, Constitutional Court Proceeding, Case Number 23/PUU-VII/2009, http://www. mahkamahkonstitusi.go.id/

\section{LAW DOCUMENTS :}

Indonesia Constitution, after amendment 1999-2002 (Undang-Undang Dasar Republik Indonesia Tahun 1945)

International Covenant on Civil and Political Rights, Adopted and opened for signature, ratification and accession by General Assembly resolution 2200A (XXI) of 16 December 1966, entry into force 23 March 1976, in accordance with Article 49, ratified by Law Number 12 of 2005.

International Covenant on Economic, Social and Cultural Rights, Adopted and opened for signature, ratification and accession by General Assembly resolution 2200A (XXI) of 16 
December 1966, entry into force 3 January 1976, in accordance with article 27, ratified by Law Number 11 of 2005 .

Law Number 10 of 2004 concerning Law Making

Law Number 44 of 2008 concerning Pornography

Syracuse Principles on the Limitation and Derogation Provisions in the International Covenant on Civil and Political Rights, U.N. Doc. E/ CN.4/1985/4, Annex. United Nations, Economic and Social Council (1985). 